\title{
Aging Results in Reduced Epidermal Growth Factor Receptor Signaling, Diminished Olfactory Neurogenesis, and Deficits in Fine Olfactory Discrimination
}

\author{
Emeka Enwere, ${ }^{\star}$ Tetsuro Shingo, ${ }^{\star}$ Christopher Gregg, Hirokazu Fujikawa, Shigeki Ohta, and Samuel Weiss \\ Genes and Development Research Group, Department of Cell Biology and Anatomy, University of Calgary Faculty of Medicine, Calgary, Alberta T2N 4N1, \\ Canada
}

Previous studies demonstrating olfactory interneuron involvement in olfactory discrimination and decreased proliferation in the forebrain subventricular zone with age led us to ask whether olfactory neurogenesis and, consequently, olfactory discrimination were impaired in aged mice. Pulse labeling showed that aged mice ( 24 months of age) had fewer new interneurons in the olfactory bulb than did young adult ( 2 months of age) mice. However, the aged mice had more olfactory interneurons in total than their younger counterparts. Aged mice exhibited no differences from young adult mice in their ability to discriminate between two discrete odors but were significantly poorer at performing discriminations between similar odors (fine olfactory discrimination). Leukemia inhibitory factor receptor heterozygote mice, which have less neurogenesis and fewer olfactory interneurons than their wild-type counterparts, performed more poorly at fine olfactory discrimination than the wild types, suggesting that olfactory neurogenesis, rather than the total number of interneurons, was responsible for fine olfactory discrimination. Immunohistochemistry and Western blot analyses revealed a selective reduction in expression levels of epidermal growth factor (EGF) receptor (EGFR) signaling elements in the aged forebrain subventricular zone. Waved-1 mutant mice, which express reduced quantities of transforming growth factor- $\alpha$, the predominant EGFR ligand in adulthood, phenocopy aged mice in olfactory neurogenesis and performance on fine olfactory discrimination tasks. These results suggest that the impairment in fine olfactory discrimination with age may result from a reduction in EGF-dependent olfactory neurogenesis.

Key words: neural stem cells; aging; forebrain SVZ; olfactory discrimination; EGF receptor; olfactory neurogenesis

\section{Introduction}

Neural stem cells (NSCs) of the basal forebrain subventricular zone (SVZ) (Reynolds and Weiss, 1992) are thought to be the precursors of new neurons (both granule and periglomerular cells) in the adult olfactory bulb (OB) in a process of neurogenesis that continues throughout the life of most adult mammals (Altman and Das, 1966; Altman, 1969; Luskin, 1993; Lois and Alvarez-Buylla, 1994; Kornack and Rakic, 2001). In the OB, the periglomerular cells surround the glomeruli, which are circular

\footnotetext{
Received April 21, 2004; revised Aug. 10, 2004; accepted Aug. 11, 2004.

This work was supported by the Canadian Institutes of Health Research (CIHR). T.S. was a recipient of a Huntington's Society of Canada/CIHR fellowship. C.G. is a recipient of an Alberta Heritage Foundation for Medical Research (AHFMR) studentship. S.O. was a recipient of a Parkinson's Society of Canada fellowship. S.W. is an AHFMR Scientist. We thank Rozina Hassam for excellent technical assistance and Drs. Bryan Kolb, Robert Sainsbury, and Derek van der Kooy as well as members of the Weiss laboratory for critical review of a previous version of this manuscript.

*E.E. and T.S. contributed equally to this work.

Correspondence should be addressed to Samuel Weiss, Genes and Development Research Group, Department of Cell Biology and Anatomy, University of Calgary Faculty of Medicine, 3330 Hospital Drive Northwest, Calgary, Alberta T2N 4N1, Canada.E-mail: weiss@ucalgary.ca.

E. Enwere's present address: Apoptosis Research Center, Children's Hospital of Eastern Ontario, 401 Smyth Road, Ottawa, Ontario K1H 8L1, Canada.

T. Shingo's present address: Department of Neurological Surgery, Okayama University Medical School, 2-5-1, Shikata-cho, Okayama 700-8558, Japan.

DOI:10.1523/JNEUROSCI.2751-04.2004

Copyright (C) 2004 Society for Neuroscience $\quad 0270-6474 / 04 / 248354-12 \$ 15.00 / 0$
}

bundles of neuropil present in the periphery of the bulb. Granule cells are present in large numbers in the deepest layer of the $\mathrm{OB}$, known as the granule cell layer. Both types of GABAergic interneurons form dendrodendritic synapses with mitral and tufted cells, which are the primary projection neurons of the bulb (Scott et al., 1993; Shipley and Ennis, 1996; Isaacson and Vitten, 2003). Olfactory receptor neurons, which convey primary olfactory information from the olfactory epithelium (OE) in the nose, form excitatory synapses with periglomerular cells but not with granule cells (Schoppa et al., 1998; Kasowski et al., 1999). Most olfactory interneurons are produced postnatally, such that their numbers increase steadily with age (Mirich et al., 2002), and studies have only recently shown that neurons produced in adulthood are physiologically functional in the OB (Carlen et al., 2002; Belluzzi et al., 2003; Carleton et al., 2003).

The functions of granule and periglomerular interneurons, and the reasons for their ongoing postnatal genesis, are poorly understood. Various studies on the intrabulbar ramifications of interneuronal processes suggest that the dendrodendritic interactions of olfactory interneurons with the projection neurons may constitute the olfactory equivalent of lateral inhibition circuits seen in the eye, indicating a possible role for these interneurons in olfactory discrimination (Laurent, 1999; Urban, 2002; Aungst et al., 2003; Egger et al., 2003). Furthermore, Gheusi et al. 
(2000) showed that mice with reduced neurogenesis exhibit impaired discrimination between discrete odors. However, they did not determine whether the impairment was attributable to the reduced neurogenesis or the associated decrease in the number of interneurons in the OB. In humans, olfactory discrimination abilities decline with age (Stevens and Cain, 1987; Hulshoff Pol et al., 2000; Kaneda et al., 2000). Thus, if mice show a similar agedependent decline in olfactory discrimination, it is reasonable to suggest that this impairment might arise because of either the increase in number of olfactory interneurons with age (Mirich et al., 2002) or the decrease in number of new neurons in the $O B$, the latter of which presumably arises from the markedly decreased SVZ proliferation seen in aging animals (Tropepe et al., 1997).

In this study, we found that in mice, fine, rather than discrete, olfactory discrimination is impaired with age, and this impairment correlates with a profound decrease in neurogenesis. We also found that the aged SVZ exhibits significant decreases in the expression of epidermal growth factor (EGF) receptor (EGFR) signaling components. An examination of waved-1 mutant mice, which are transforming growth factor- $\alpha$ (TGF $\alpha$ ) hypomorphs with reduced EGFR signaling, indicated that they phenocopy aged mice in neurogenesis and fine discrimination capabilities, suggesting that reduced EGF-dependent neurogenesis contributes to the decline in olfactory discrimination that occurs with age.

\section{Materials and Methods}

Animals. Adult C57BL/6, BALB/c, CBA, and DBA mice were obtained from the National Institute on Aging (Bethesda, MD). Waved-1 mutant mice (B6.Cg-Tgfa ${ }^{\text {wal }} / \mathrm{J}$ ), which have a spontaneous mutation resulting in decreased TGF $\alpha$ levels, were obtained from Jackson Laboratories (Bar Harbor, ME). Mice homozygous for the Tgfa ${ }^{\text {wal }}$ mutation $\left(T g f a^{\text {wal } / \text { wal }}\right.$ ) can be identified at 2 or $3 \mathrm{~d}$ of age by their curly whiskers and fur. Leukemia inhibitory factor receptor heterozygote $\left(\mathrm{Lifr}^{+/-}\right)$mice, generated on the B6.129/J background, were also obtained from Jackson Laboratories. Heterozygosity of mice carrying Lifr mutations was performed by PCR amplification as described previously (Shimazaki et al., 2001) of the neo insert. Because mice homozygous for the Lifr mutation do not survive beyond birth, primers for Lifr detection were unnecessary. Primers for neo detection were: $5^{\prime}$-CTTGGGTGGAGAGGCTATTC-3' (sense strand) and 5'-AGGTGAGATGACAGGAGATC-3' (antisense strand). These amplified a $280 \mathrm{bp}$ product. All animals were maintained on a $12 \mathrm{hr}$ light/dark cycle with food and water ad libidum unless otherwise indicated.

Neural stem cell culture. The procedures used to generate neurospheres from the adult forebrain were adopted as described previously (Weiss et al., 1996; Shimazaki et al., 2001; Shingo et al., 2001). Briefly, adult mice were killed by cervical dislocation, and the removed brains were placed into Petri dishes containing PBS. Tissue was dissected from a defined region surrounding the lateral ventricles, extending from the rostral tip to the crossing point of both ventricles (without contamination of the cortex and hippocampus). Dissected tissues were transferred into a defined media-hormone mixture containing $1.33 \mathrm{mg} / \mathrm{ml}$ trypsin, 0.67 $\mathrm{mg} / \mathrm{ml}$ hyaluronidase, and $0.2 \mathrm{mg} / \mathrm{ml}$ kynurenic acid (all from Sigma, St. Louis, MO) and then incubated for $20 \mathrm{~min}$ at $37^{\circ} \mathrm{C}$. After complete trituration with a micropipette, the suspension was transferred into the same volume of media containing $0.7 \mathrm{mg} / \mathrm{ml}$ trypsin inhibitor (Sigma). This suspension was spun down at $600 \mathrm{rpm}$ for $5 \mathrm{~min}$, resuspended, and then plated at a density of $1000-2000$ cells $/ \mathrm{ml}$ in a six-well plate in EGFcontaining media.

Bromodeoxyuridine labeling and detection. Mice were injected with bromodeoxyuridine (BrdU (120 mg/kg, i.p., dissolved in $0.007 \% \mathrm{NaOH}$ in phosphate buffer; Sigma) every $2 \mathrm{hr}$ for $10 \mathrm{hr}$ and were deeply anesthetized with pentobarbitol $0.5 \mathrm{hr}$ or 4 weeks after the last injection. Brains were processed for immunohistochemistry as described below.
Rat monoclonal anti-BrdU (1:50; Cedarlane, Hornby, Ontario, Canada) and biotinylated-donkey anti-rat (1:200; Jackson ImmunoResearch, West Grove, PA) with streptavidin-cyanine 3 (Cy3) (1:2000; Jackson ImmunoResearch) were used for BrdU detection.

EGF and cytosine arabinsoside infusion. Adult C57BL/6 mice were anesthetized with sodium pentobarbital $(120 \mathrm{mg} / \mathrm{kg}$, i.p.) and implanted with an osmotic pump (Alzet 1003D; Alza, Palo Alto, CA). For EGF and cytosine arabinsoside (AraC) infusions, the cannula was located in the right lateral ventricle (anteroposterior, $+0.2 \mathrm{~mm}$; lateral, $+0.8 \mathrm{~mm}$ to bregma; dorsoventral, $-2.5 \mathrm{~mm}$ below dura with the skull leveled between $\lambda$ and bregma). Human recombinant EGF $(16.5 \mu \mathrm{g} / \mathrm{ml})$ or AraC (2\%) was dissolved in $0.9 \%$ saline containing 1 $\mathrm{mg} / \mathrm{ml}$ mouse serum albumin (Sigma). Each animal was infused for three consecutive days at a flow rate of $1.0 \mu \mathrm{l} / \mathrm{hr}$, resulting in a delivery of $\sim 0.4 \mu \mathrm{g} / \mathrm{EGF} / \mathrm{d}$.

Immunohistochemistry. Animals were deeply anesthetized and perfused transcardially with $30 \mathrm{ml}$ of PBS and $30 \mathrm{ml}$ of $4 \%$ paraformaldehyde in PBS, $\mathrm{pH}$ 7.2. Brains were postfixed in the perfusing solution overnight at $4^{\circ} \mathrm{C}$ and then cryoprotected for at least $24 \mathrm{hr}$ in $20 \%$ sucrose in PBS. The brains were coronally cut at the anterior tip of the corpus callosum to provide for sagittal or coronal sections of the $\mathrm{OB}$ and rostral migratory stream (RMS) and coronal sections of the SVZ and then embedded in Tissue Tek OCT compound (Sakura Finetek, Torrance, CA) before they were cryosectioned at $14 \mu \mathrm{m}$. The following primary antibodies (final dilution and source) were used for tissue staining: sheep anti-EGF receptor (1:50; BioDesign, Saco, ME), goat anti-CNTF receptor (CNTFR; 1:50; Santa Cruz Biotechnology, Santa Cruz, CA), rabbit antityrosine hydroxylase (TH; 1:200; Pel-Freez, Rogers, AR), rabbit antiKi67 (1:200; Novocastro Laboratories, Newcastle upon Tyne, UK), mouse anti-mammalian achaete-schute homolog 1 (MASH1; 1:5; provided by Dr. D. Anderson, Caltech, Pasadena, CA), mouse antineuronal-specific nuclear protein (1:100; Chemicon, Temecula, CA), and rat anti-polysialic acid (PSA)-neural cell adhesion molecule (NCAM) IgM (1:100; BD Biosciences, Franklin Lake, NJ). For BrdU staining, tissues were pretreated with $1 \mathrm{~N} \mathrm{HCl}$ for $30 \mathrm{~min}$ at $60^{\circ} \mathrm{C}$ to denature cellular DNA. Sections were incubated for $24 \mathrm{hr}$ at $4^{\circ} \mathrm{C}$ in primary antibody diluted in $0.3 \%$ Triton X-100/PBS containing NGS, washed with PBS, and then incubated with regular secondary antibodies conjugated to FITC, rhodamine, or biotinylated secondary antibodies for $1 \mathrm{hr}$ at room temperature followed by incubation with streptavidin-Cy3 for $1 \mathrm{hr}$ at room temperature together with Hoechst 33258. After rinsing with water, sections were mounted with Fluorsave and viewed or photographed with a Zeiss Axiophot fluorescence microscope (Zeiss, Thornwood, NY).

Terminal deoxynucleotidyl transferase-mediated biotinylated UTP nick end labeling staining. To detect cells undergoing apoptosis, an In Situ Death Detection kit (Roche Diagnostics, Hertfordshire, UK) was used. In brief, tissue sections were permeabilized with $0.001 \mathrm{mg} / \mathrm{ml}$ proteinase $\mathrm{K}$ in Tris- $\mathrm{HCl}$ for $10 \mathrm{~min}$ at room temperature and then incubated with fluorescein-positive terminal deoxynucleotidyl transferase-mediated biotinylated UTP nick end labeling (TUNEL) reaction mixture for $90 \mathrm{~min}$ at $37^{\circ} \mathrm{C}$. Labeled cells were counterstained and counted in the SVZ and $\mathrm{OB}$ as described below.

Quantification. Quantification of immunoreactive cells was performed as described previously (Shingo et al., 2001) and summarized briefly here. For the SVZ, a one-in-eight series of coronal sections (14 $\mu \mathrm{m}$ ) from the rostral tip of the lateral ventricle to a distance of $980 \mu \mathrm{m}$ caudal (total of 10 sections) was performed. BrdU-, Ki67-, MASH1-, and PSA-NCAM-positive cells were counted in the defined ependymal-subependymal layer or dorsolateral corner of the SVZ, which could be visualized by Hoechst staining. For the OB, a one-in-eight series of coronal sections $(14 \mu \mathrm{m})$, including the anterior extent of the accessory olfactory bulb, and all tissue $1020 \mu \mathrm{m}$ rostral (total of 10 sections) was collected. Every eighth section was selected for quantification. TH- and BrdUpositive cells were counted in the granule and glomerular cell layers of the OB. Analysis of significant differences was performed using the Student's $t$ test to compare values within experiments.

Western blot analysis. After mice were killed by cervical dislocation, the defined tissue surrounding the lateral ventricles was dissected away. Tis- 
sues were homogenized in radioimmunoprecipitation assay buffer $(1 \%$ Nonidet P-40, $0.5 \%$ sodium deoxycholate, $0.1 \%$ SDS in PBS) with a protease inhibitor mixture (Roche). Equivalent amounts of extracted proteins $(20 \mu \mathrm{g})$ were loaded on each lane of a $7.5 \%$ polyacrylamide gel for CNTFR and EGFR (or $12 \%$ for the TGF $\alpha$ blots) and transferred to a nitrocellulose membrane (Bio-Rad, Cambridge, MA). Membranes were blocked for $2 \mathrm{hr}$ with 5\% skim milk in TBS-T (10 mm Tris-HCl, $150 \mathrm{~mm}$ $\mathrm{NaCl}, 0.1 \%$ Tween 20 ) and incubated with primary antibody overnight at $4^{\circ} \mathrm{C}$ and then with a secondary antibody conjugated with peroxidase for $1 \mathrm{hr}$ at room temperature. After extensive washing, immunoreactivity was developed by enhanced chemiluminescence (Amersham Biosciences, Arlington Heights, IL). Membranes were stripped with stripping buffer (Pierce, Rockford, IL) and reprobed with anti-actin antibody. Primary antibodies used were sheep anti-EGFR (1:1000; BioDesign), goat anti-CNTFR $\alpha$ (1:500; Santa Cruz Biotechnology), goat anti-TGF $\alpha$ ( $1 \mu \mathrm{g} / \mathrm{ml}$; R \& D Systems, Minneapolis, MN), and goat anti-actin (1: 1000; Santa Cruz Biotechnology). Secondary antibodies conjugated with peroxidase were donkey anti-goat or donkey anti-sheep IgG (1:5000; Jackson ImmunoResearch). The intensity of the bands was measured using NIH imaging software.

Olfactory discrimination. Mice were separated into individual cages and water-deprived for $48 \mathrm{hr}$. All testing was conducted in the home cage, and trial sessions consisted of the following two stages: a training stage and a testing stage. For the very first training stage, $12 \mu \mathrm{l}$ of doubledistilled water was placed in a sterile $35 \times 10 \mathrm{~mm}$ tissue culture dish, and $1 \mu \mathrm{l}$ of coconut extract (COC) was applied to the surface of the water. This initial combination of double-distilled water and COC served as a reward for response and was designated $[+]$. The dish was placed at one end of the cage, and the mouse was allowed 2 min to find and drink the $[+]$. Once the mouse finished drinking, the dish was removed and replaced with a fresh $[+]$ solution after a $30 \mathrm{sec}$ inter-trial interval. The amount of COC was increased with each trial until it reached $8.5 \mu \mathrm{l}$ per dish per trial. From here, five trials were conducted using $[+]$. For the sixth trial, we presented the mice with culture dishes containing $8.5 \mu \mathrm{l}$ of almond extract (ALM) applied to the surface of $12 \mu \mathrm{l}$ of a $1 \%$ solution of denatonium benzoate (DB) (Sigma). This combination of ALM and DB was designated $[-]$. Because DB is extremely bitter, the mice found it extremely aversive and learned to associate the bitter taste with the smell of ALM. They subsequently avoided drinking the [-]. We conducted four additional trials with $[-]$ to ensure that the mice had indeed learned to avoid the [-] and with this concluded each training stage. In the testing stage, we presented the animals with two dishes, one of which contained $[+]$, whereas the other contained $[-]$. The mice thus had the option of selecting which dish to drink from, again within the 2 min time limit. A successful discrimination was one in which the mouse tasted or drank the $[+]$. There were three criteria for failure: $(1)$ if the mice chose the $[-]$ rather than the $[+] ;(2)$ if the mice chose the $[+]$ but within 30 sec of that selection went on to select the $[-]$, indicating that they could not effectively discriminate between the two; (3) if the mice made no selections in the $2 \mathrm{~min}$ allocated to each trial. In a failed discrimination, both dishes were immediately removed from the cage, concluding the trial. This continued for a total of 10 trials per testing stage. We alternated the positions of $[+]$ and $[-]$ at random from trial to trial to prevent the mice from making selection decisions based on location. Furthermore, two extra error-checking (unrecorded) trials in which both dishes contained only $[+]$ were inserted within the body of the testing stage. The function of this subtask was to prevent a high-performing animal from ignoring the second dish after successfully sampling the first. The mice were thus placed on a variable reinforcement schedule whereby they were trained to believe that there were always two possible solutions to any discrimination trial and ensured that they would sniff at the $[-]$ even after correctly selecting the $[+]$ in a trial. Thus, the theoretical minimum performance per session (percentage of successful discrimination trials of the total number of trials) became $0 \%$ instead of the $50 \%$ success rate expected at chance levels, and the power of the task was thus increased. In additional sessions (specifically in the generalization gradient), the COC and ALM in the $[+]$ and $[-]$, respectively, were replaced with various mixtures of both COC and ALM. In each case, an appropriate training stage using the new $[+]$ and $[-]$ preceded the testing stage.

\section{Results \\ Aged mice demonstrate impairment in fine olfactory discrimination}

Pathology within the OE may be considered the most obvious and distinctive origin of age-related olfactory dysfunction. The $\mathrm{OE}$ is susceptible to significant levels of cellular apoptosis and injury caused by its direct contact with the external environment (Conley et al., 2003). Consequently, it is normally capable of regenerating the olfactory receptor neurons lost through these processes. This regenerative capacity is lost with age, leading to eventual permanent degradation (Loo et al., 1996; Weiler and Farbman, 1997; Rosli et al., 1999; Conley et al., 2003). Demonstration of a role for the aged $\mathrm{OB}$ in olfactory discrimination, therefore, requires elimination of the $\mathrm{OE}$ as a possible confound. To this end, we devised a test (supplemental material, available at www.jneurosci.org) to reliably measure subtle differences in the ability to perform olfactory discriminations between animal groups while ensuring that the discriminants are present in sufficient quantities to overcome sensory deficits. Briefly (see Materials and Methods for details), mice were water-deprived for $48 \mathrm{hr}$ and presented with sterile plastic dishes containing $8.5 \mu \mathrm{l}$ of COC as odorant in $12 \mu \mathrm{l}$ of double-distilled water. An important point of note is that training was started with $1 \mu \mathrm{l}$ of odorant per sample, which all animals could detect, with the quantity gradually increased to an excess of $8.5 \mu \mathrm{l}$ per sample. The combination of $\mathrm{COC}$ and water was designated [+]. After five presentations of $[+]$, the mice were then offered dishes containing $8.5 \mu$ l of ALM in $12 \mu \mathrm{l}$ of $1 \%$ denatonium benzoate, which is extremely bitter. This combination was designated [-]. Typically, the mice sampled this solution only once or twice; nevertheless, they were presented with $[-]$ for five trials lasting a maximum of $2 \mathrm{~min}$ each. Ten trials followed in which $[+]$ and $[-]$ were presented to the mice side by side. Because both solutions were colorless and visually identical, the mice could only discriminate between them by smell. Trials were scored as successful if the mice drank the $[+]$ and did not go on to drink the $[-]$ within $30 \mathrm{sec}$ of making this choice. To ensure that observed effects were not caused by innate preferences for one odor over the other, ALM and COC were used in reversed situations (i.e., ALM in $[+]$ and COC in $[-])$. In those cases, the results were similar to those seen in the experiments described here (data not shown).

To determine whether aged mice demonstrated olfactory discrimination deficits, not because of degradation of the $\mathrm{OE}$, we trained and evaluated young adult ( 2 months of age) and aged ( 24 months of age) male C57BL/6 mice on the discrimination test as described. Both young and aged mice were equally adept at olfactory discrimination between COC and ALM, averaging 80-90\% success rates (Fig. 1). These results showed that aged mice were not impaired at detecting the discrete odors present at excess in both solutions, thus eliminating any differences in sensitivity that may arise from the degenerating $\mathrm{OE}$ in the aged mice. However, the test as described could not resolve subtle or fine differences in discrimination. To achieve this, the mice underwent additional series of retraining and retesting with $[+]$ and $[-]$ that were increasingly similar (by creating mixtures of COC and ALM in $[+]$ and $[-])$ to produce a graph of performance against odor concentration known as a generalization gradient. Thus, for each gradient, mice were required to discriminate between solutions containing ratios of COC:ALM of 100:0, which is a basic discrim- 


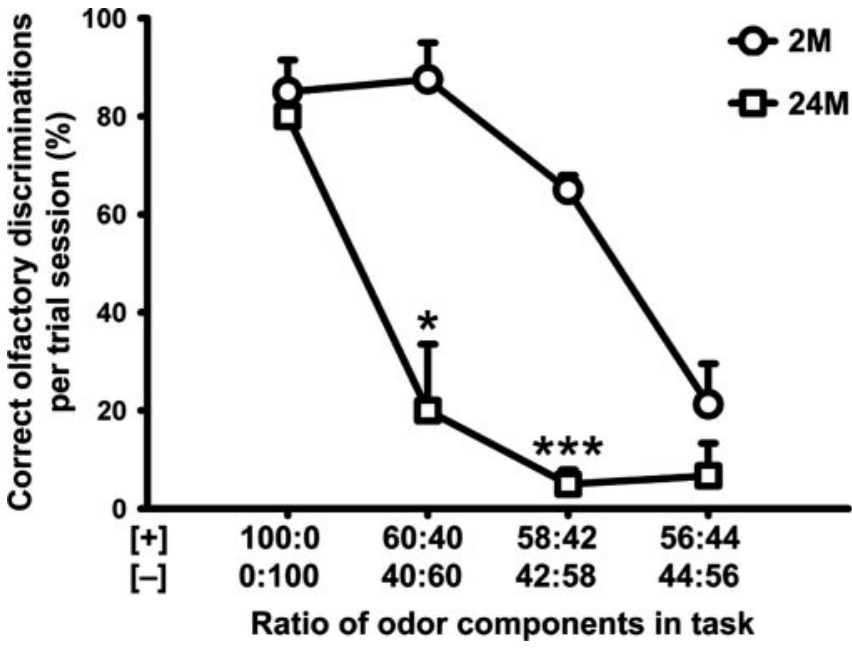

Figure 1. Olfactory discrimination generalization gradient, with male 2-month-old (2M) and 24-month-old (24M) C57BL/6 mice. Ratios along the abscissa represent COC:ALM concentration ratios used in [+] (top line) and in [-] (bottom line). The number of successful discriminations per trial session was expressed as a percentage of total trials per session. ${ }^{*} p<0.05$ and ${ }^{* * *} p<0.001$ versus the 2 -month-old animals; Student's $t$ test.

ination between discrete odors, as well as 60:40, 58:42, and 56:44 (all ratios hereinafter refer to the COC:ALM ratio in $[+]$; the corresponding [-] ratios can be inferred to be the inverse, i.e., COC:ALM 0:100, 40:60, etc.). At 60:40, the performance of the 24-month-old mice declined sharply, such that they succeeded at only $20 \%$ of the discriminations, compared with a performance of $88 \%$ with the 2 -month-old mice (Fig. 1$)(n=4 ; p<0.05)$. The differences persisted through 58:42, where the 24- and 2-monthold mice succeeded at 5 and $65 \%$ of the discriminations, respectively $(p<0.001)$. At 56:44, the performances of the 2-monthold mice declined $(21 \%)$ such that they were no longer different from those of the 24 -month-old mice $(7 \% ; p>0.05)$. These results show that aged mice are impaired at fine, but not discrete, olfactory discriminations, likely because of deficits arising in the CNS aspect of the olfactory pathway.

\section{The impairment of fine olfactory discrimination with age is} associated with a reduction in the number of new neurons in the OB

We next asked whether changes in neurogenesis in the $\mathrm{OB}$ were responsible for the poor performance of the aged animals at fine olfactory discrimination. As stated in Introduction, we hypothesized that this impairment might result from either an increase in the total number of interneurons, which a previous study has suggested to occur in both the granule and glomerular layers with age (Mirich et al., 2002), or a decrease in the number of new neurons in the $\mathrm{OB}$. To first confirm that there is an increase in the total number of interneurons that occurs with age, we focused on the glomerular layer and labeled periglomerular cells in 2- and 24-month-old OBs with an antibody against TH. The 24-monthold mice had $44 \%$ more periglomerular cells than the 2 -monthold mice (Table $1 ; p<0.05 ; n=3$ ). To address the possibility that impaired discrimination arose from a corresponding reduction in the number of new periglomerular interneurons in the aged $\mathrm{OB}$, we administered injections of BrdU to 2- and 24-month-old mice, perfused them 4 weeks later, and labeled OB sections with antibodies against BrdU and $\mathrm{TH}$. The aged animals had 71\% fewer BrdU and TH double-labeled neurons in the glomerular
Table 1. Aged mice exhibit decreases in neurogenesis but increases in number of olfactory interneurons

\begin{tabular}{lcc}
\hline & Age \\
\cline { 2 - 3 } Cells/structure & 2 Months & 24 Months \\
\hline TH-positive periglomerular cells & $1710 \pm 153$ & $2455 \pm 258^{*}$ \\
BrdU/TH double-labeled cells in the OB & $193 \pm 15$ & $56 \pm 2^{* *}$ \\
TUNEL-positive cells in the OB & $5 \pm 1$ & $11 \pm 5$ \\
\hline
\end{tabular}

The numbers of immunoreactive cells in the OB. Data presented represent the mean \pm SEM. ${ }^{*} p<0.05$ versus 2 months: $* * 0.01$ versus 2 months.

layer of the OB than the younger mice (Fig. 2, Table 1) $(p<0.01$; $n=3$ ). A similar analysis of BrdU and calretinin double-labeled periglomerular neurons (Fig. 2), which represents a nonoverlapping population in the glomerular layer (Kosaka et al., 1998), showed that aging animals had a $59 \%(p<0.05 ; n=3)$ reduction. This suggests that the reduction in neurogenesis is not restricted to one periglomerular neuron phenotype. Although there was a clear decrease in BrdU throughout the OB of 24month-old mice (Fig. 2), we wanted to unambiguously establish that the reduction in new interneurons was a phenomenon that occurs in both principal interneuronal layers. To do this, we labeled OB sections with antibodies against BrdU and GABA and examined the relative numbers in both the granule and glomerular layers of 2- and 24-month-old mice (Fig. 2). Aged mice had 55\% $(p<0.05 ; n=3)$ and $41 \%(p<0.05 ; n=3)$ fewer BrdU and GABA double-labeled neurons in the granule and glomerular layers, respectively, compared with the younger mice. These results suggest that reduced neurogenesis, as is the case for increased total cell number (Mirich et al., 2002), is observed in both the granule and glomerular layers of the aged OB. Moreover, there was no difference in the number of TUNEL-positive cells (Table 1), indicating that increased cell death in the aged mice OBs was not responsible for the difference in number of new neurons.

To determine whether the age-related deficit in olfactory discrimination resulted from the increase in olfactory interneuron number or from a decrease in the level of neurogenesis, we examined leukemia inhibitory factor receptor heterozygote $\left(\mathrm{Lifr}^{+{ }^{-}}\right)$ mice, which have fewer olfactory interneurons and less neurogenesis than their Lifr $^{+/+}$littermates as described previously (Shimazaki et al., 2001). We hypothesized that if it is the increase in total number of interneurons that is responsible for the impairment in fine olfactory discrimination in aged mice, then the Lifr $^{+/-}$mice, which have fewer interneurons than the Lifr ${ }^{+/+}$ mice, should perform better on the olfactory discrimination generalization gradient. If reduced neurogenesis was responsible for the impairment, then the Lifr ${ }^{+/+}$mice should surpass the Lifr $^{+/-}$mice at olfactory discrimination. We trained and evaluated age-matched 6- to 7-month-old iffr $^{+/-}$and Lifr ${ }^{+/+}$(when both neurogenesis and interneuron numbers are significantly reduced) (T. Shimazaki and S. Weiss, unpublished observations) on the olfactory discrimination generalization gradient. There was no difference in performance between Lifr $^{+/-}$and Lifr ${ }^{+/+}$ groups at 100:0 (Fig. 3) or at 60:40. However, the Lifr $^{+/-}$mice performed more poorly than their Lifr ${ }^{+/+}$counterparts at 58:42 ( 7.5 vs 35\%, respectively; $p<0.05 ; n=4$ ) and at 56:44 (0 vs 20\%, respectively; $p<0.05$ ). Collectively, these data suggest that fine olfactory discrimination is impaired by reduced neurogenesis, rather than by the absolute number of olfactory interneurons present in the $\mathrm{OB}$. 

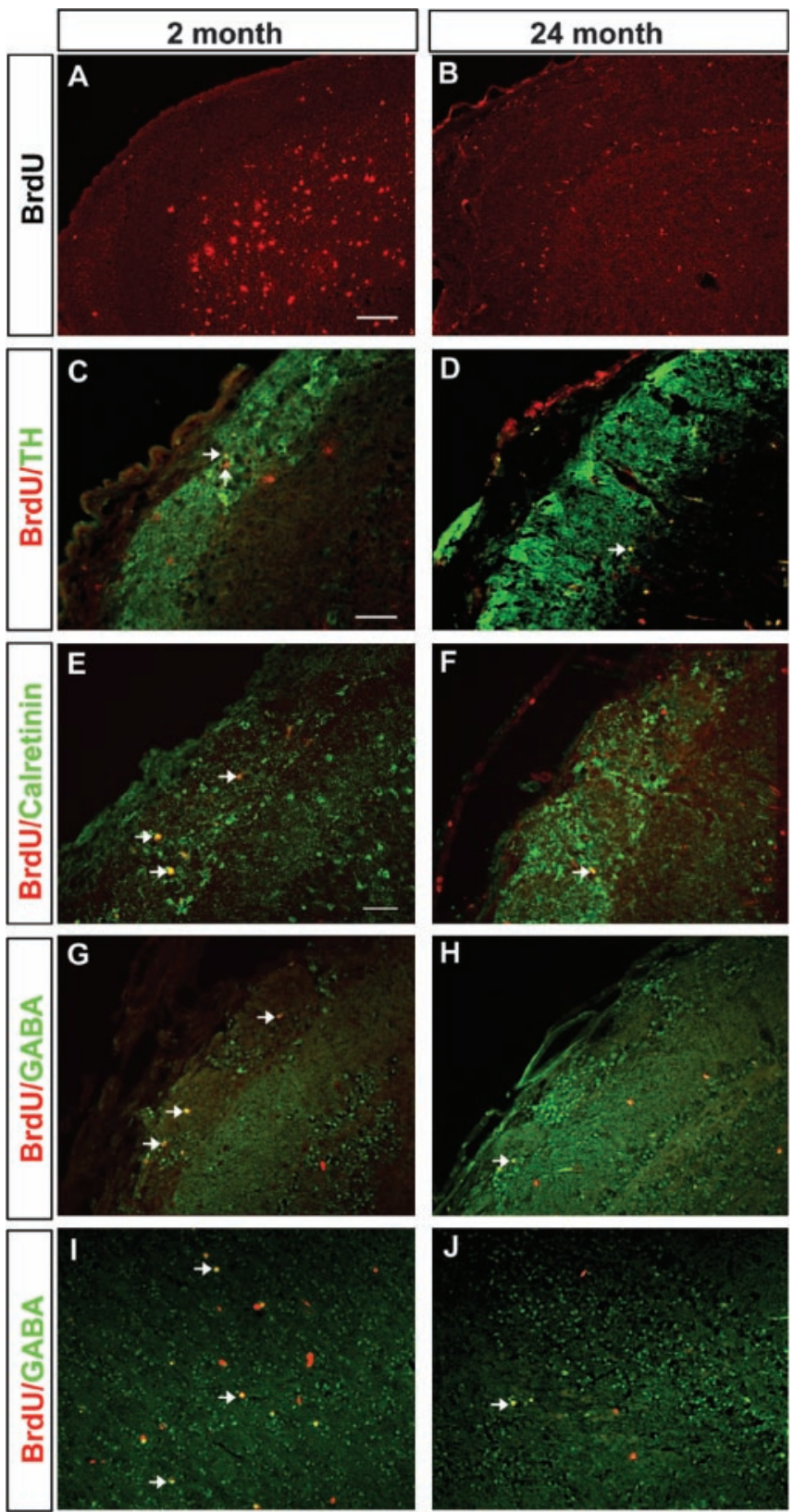

Figure 2. Aged mice have fewer newly generated olfactory interneurons than younger mice. $A, B$, In 2-month-old mice, 4 weeks after BrdU administration, a large number of BrdU-positive cells (red) was located throughout the $O B$, whereas a dramatic decrease in the number of BrdU-positive cells was observed in the $O B$ of 24-month-old animals. C, D, An analysis of the interneuronal subpopulations of the $O B$ revealed a decrease in the number of TH plus BrdU periglomerular neurons in 24-month-old versus 2-month-old mice; nevertheless, the glomerular layer was considerably larger in the 24-month-old mice than the 2-month-old mice. $E-H$, Decreases in the number of calretinin plus $\operatorname{BrdU}(E, F)$ and $G A B A$ plus $\operatorname{BrdU}(G, H)$ cells were also observed in the glomerular layer of aged versus young mice. $I, J$, This decrease in neurogenesis was not restricted to the glomerular layer, because a decrease in the number of GABA plus BrdU-expressing cells was observed in the granule cell layer of aged animals as well. For corresponding data, see Results and Table 1. Scale bars: $A, C, 100 \mu \mathrm{m}$; (in $E) E-J, 50 \mu \mathrm{m}$. Arrows indicate examples of double-labeled cells.

Reduction of olfactory neurogenesis with age results from a decrease in the number of forebrain NSCs and associated SVZ proliferation

The results to this point suggest that, despite an increased number of interneurons in the OB, aged mice have decreased levels of

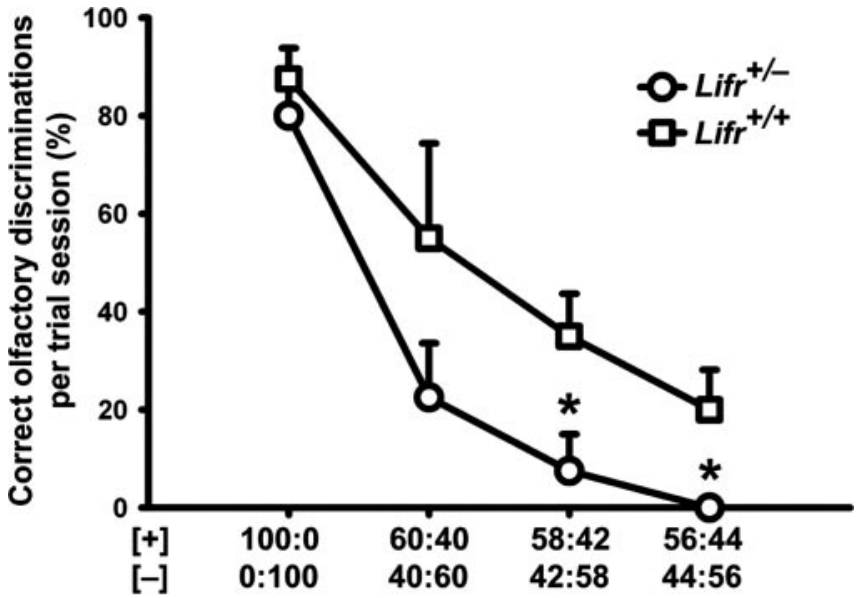

Ratio of odor components in task

Figure 3. Lifr ${ }^{+/-}$mutant mice are impaired at fine olfactory discrimination. Six-month-old to 7 -month-old Lifr $^{+/+}$and Lifr $^{+/-}$mice were assessed for olfactory discrimination on a generalization gradient. ${ }^{*} p<0.05$ with respect to the Lifr $^{+/+}$mice; Student's $t$ test.

neurogenesis relative to younger mice. We went on to determine the physiological basis of this discrepancy by evaluating neurogenesis at the level of the SVZ. Two- and 24-month-old mice were given six injections of BrdU over the course of $10 \mathrm{hr}$ and were perfused one-half hour after the last injection. Immunohistochemistry against BrdU revealed a reduction of $75 \%$ in the total number of BrdU-positive cells in the SVZs of aged mice (Fig. 4, Table 2) $(p<0.01 ; n=4)$. However, Tropepe et al. (1997), who performed similar experiments, suggested that the reduction in proliferation detected with BrdU might result from a lengthening of the cell cycle rather than from a bona fide reduction in the number of progenitor cells. In such an instance, the labeling paradigm that captures most of the proliferating cells in 2-monthold animals would underestimate the number of proliferating cells in 24-month-old animals. Therefore, to confirm the results of the BrdU experiments, we also counted the number of cells immunoreactive for Ki67, which is a cell cycle-related protein expressed in the nuclei of proliferating cells (Giardino et al., 2000; Ohta and Ichimura, 2000). The 24-month-old mice exhibited an $83 \%$ loss of Ki67-positive cells compared with the 2-month-old mice (Table 2; $p<0.01 ; n=3$ ), thus verifying the results of the BrdU experiments.

We also asked whether the reduction in number of proliferating cells in the SVZ was reflected in a decrease in number of neuronal progenitors. To this end, we analyzed the dorsolateral corner of the SVZ from which neuronal progenitors depart for the OB. Immunohistochemistry, using an antibody directed against the SVZ progenitor cell marker PSA-NCAM (Doetsch et al., 1997), also labeled neuronal progenitors. Although the 24month-old animals showed a small but significant decrease in the number of PSA-NCAM-positive cells in the SVZ, not including the dorsolateral corner (Table 2) $(26 \% ; p<0.05 ; n=4)$, the number of PSA-NCAM-positive cells in the dorsolateral corner itself was reduced by $66 \%(p<0.05 ; n=4)$. In a previous study, we showed that an antibody against MASH1 protein labels a population of neuronal progenitors that are restricted to the dorsolateral corner of the SVZ (Shingo et al., 2003). Here, in the 24-month-old SVZ, the number of MASH1-positive cells was reduced by $79 \%$ with respect to the 2 -month-old SVZ (Fig. 4, Table 2) $(p<0.01 ; n=4)$. The absolute number of 

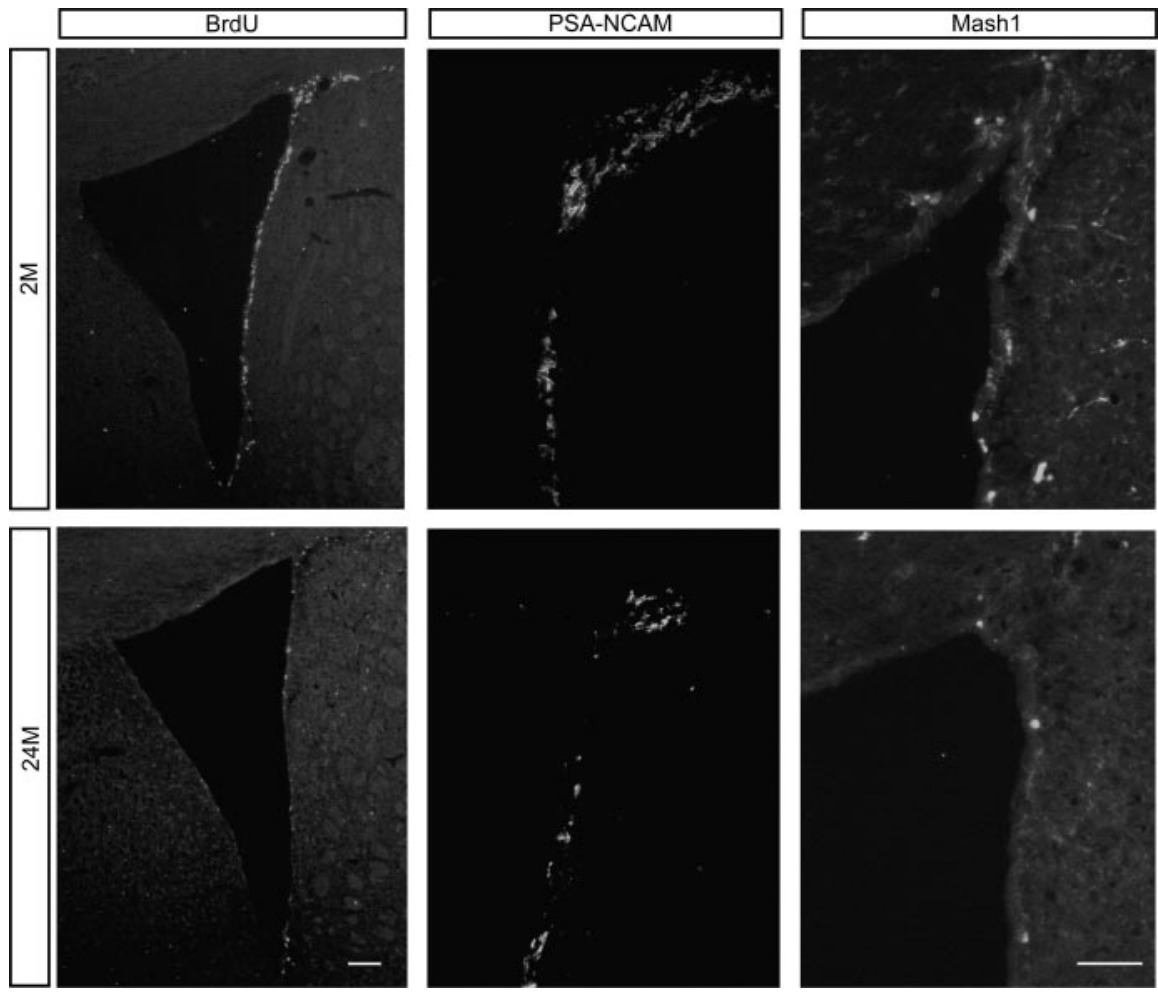

Figure 4. The number of proliferating cells in the SVZ and dorsolateral corner decreases with age. There are fewer proliferating cells (BrdU labeled) seen in 2-month-old (2M) SVZs than in those of 24-month-old (24M) SVZs. Similarly, the numbers of neuronal progenitors immunoreactive for PSA-NCAM and MASH1 in the dorsolateral corner of the SVZ, seen in 2-month-old mice, are significantly reduced in their 24-month-old counterparts. The corresponding quantitative data are in Table 2. Scale bars: (in bottom left) top left, bottom left, $100 \mu \mathrm{m}$; (in bottom right) middle and right, $50 \mu \mathrm{m}$.

Table 2. Comparison of NSC proliferation and neurogenesis in the young versus aged forebrain SVZ

\begin{tabular}{lcc}
\hline & \multicolumn{2}{l}{ Age } \\
\cline { 2 - 3 } Cells/structure & 2 Months & 24 Months \\
\hline Number of forebrain NSCs & $881 \pm 60$ & $189 \pm 38^{* *}$ \\
BrdU cells in the SVZ & $1516 \pm 76$ & $371 \pm 22^{* *}$ \\
Ki67-positive cells in the SVZ & $1738 \pm 123$ & $303 \pm 96^{* *}$ \\
PSA-NCAM-positive cells in the SVZ & $670 \pm 27$ & $498 \pm 41^{*}$ \\
PSA-NCAM-positive cells in the dorsolateral corner & & \\
$\quad$ of the SVZ & $506 \pm 47$ & $174 \pm 21^{*}$ \\
MASH1-positive cells in the dorsolateral corner of & & \\
$\quad$ the SVZ & $535 \pm 25$ & $110 \pm 17^{* *}$ \\
BrdU-positive cells in the RMS & $400 \pm 11$ & $89 \pm 7^{* *}$ \\
\hline
\end{tabular}

The numbers of immunoreactive cells in the adult forebrain SVZ or RMS were determined as described in Materials and Methods. Data presented represent the mean \pm SEM. ${ }^{*} p<0.05$ versus 2 months; ${ }^{* *} p<0.01$ versus 2 months.

BrdU-positive cells migrating along the rostral migratory stream was similarly diminished by $77 \%$ (Table 2$)(p<0.01$; $n=4)$.

Studies from our laboratory and others (Shimazaki et al., 2001; Machold et al., 2003) suggest that there is a correlation between the numbers of NSCs present in the SVZ and the extent of neurogenesis in the same region. Therefore, we asked whether the decrease in the number of proliferating neural progenitors in the forebrain SVZ was attributable to a reduction in the number of NSCs with age in the same region. Adult NSCs can proliferate in vitro in the presence of EGF and/or FGF-2 to form clusters of multipotent proliferating cells known as neurospheres (Reynolds and Weiss, 1992; Weiss et al., 1996). Accordingly, in our study of the changing properties of NSCs with age, we used this sphere-forming assay to determine the numbers of EGF-responsive NSCs present in the adult forebrain SVZ. We derived $\sim 900$ spheres from the forebrain of each 2-month-old male C57BL/6 mouse. In contrast, forebrains from the 24-month-old mice produced only $\sim 200$ spheres each (Table 2$)(p<0.01 ; n=4)$. This constituted a reduction of $77 \%$ in the number of NSCs in the aged SVZ, a figure that is virtually identical to the reduction in the numbers of BrdU-positive cells. Given that the genetic background of the mice used in this study differ from that studied by Tropepe et al. (1997), we further examined the effects of age on three other mouse strains with different genetic backgrounds (Table 3). Although there were some differences in the absolute numbers of neurospheres generated, all three other mouse strains examined showed a virtually identical, significant, age-dependent reduction in the numbers of forebrain NSCs. Together, these results suggest that a reduction in forebrain NSC number results in a proportional reduction in the numbers of neuronal progenitors and, in turn, new neurons migrating to the $\mathrm{OB}$.

\section{Selective reduction of EGFR signaling} components in the aged forebrain SVZ results in reduced $S V Z$ proliferation potential, whereas the intrinsic proliferative-regenerative capacity of the SVZ is unchanged

We next asked which mechanisms were responsible for the decrease in NSC numbers and SVZ neurogenesis with age. Previous studies from our laboratory and others suggest that EGFR signaling is necessary for the proliferation of adult forebrain SVZ NSCs and their progeny (Reynolds and Weiss, 1992; Weickert and Blum, 1995; Weiss et al., 1996; Tropepe et al., 1997). Furthermore, we recently found that the EGFR and CNTFR $\alpha /$ LIFR/ gp130 signaling systems may cooperatively regulate NSC proliferation and self-renewal (Shimazaki et al., 2001) by synergistically enhancing Notch1 expression and activation (Chojnacki et al., 2003). We thus asked whether the levels of expression of the receptors in these signaling systems changed during the aging process. We examined the expression of both EGFR and CNTFR $\alpha$ in vivo by immunohistochemistry (Fig. $5 A$ ). There appeared to be fewer cells expressing high levels of EGFR in the aged SVZ. This was particularly apparent in the lateral and dorsolateral aspects of the SVZ, which are the principle sources of neuronal progenitors. In contrast, expression of CNTFR $\alpha$ appeared identical between the age groups. To confirm these observations, we dissected out the SVZs of 2- and 24-month-old mice and isolated total protein for Western blot analysis. Here, we again examined expression levels of EGFR and CNTFR $\alpha$ as well as those of TGF $\alpha$, which is the EGFR ligand that predominates in the adult CNS (Kaser et al., 1992). We found no differences in CNTFR $\alpha$ expression levels between the 2- and 24-month-old animals (Fig. $5 B, C$ ). In contrast, levels of EGFR and TGF $\alpha$ ex- 
pression were reduced by $\sim 50$ and $70 \%$, respectively. Preliminary studies have also found that expressions of other components of the CNTFR/LIFR/gp130 signaling system are not reduced in the aged SVZs (Shingo and Weiss, unpublished observations). Together, these findings indicate that age results in significant and selective reductions in critical components of EGFR signaling in the forebrain SVZ.

The decreased EGFR signaling should result in a reduction in the capacity of EGF to expand the constitutively proliferating population of the SVZ. To test whether this might be the case, we infused EGF into the lateral ventricles for $3 \mathrm{~d}$ and used BrdU injections to count the numbers of proliferating cells in the adult SVZ (Fig. $6 \mathrm{~A}$ ). In 2 -month-old mice, EGF induced an $82 \%$ increase in the numbers of proliferating cells, whereas the same infusion resulted in only a $38 \%$ increase in the 24 -month-old mice. These results suggest that the expansion potential of NSC progeny may be reduced because of a reduction in EGF receptor signaling. In a previous study (Morshead et al., 1994), we found that after ablation of the constitutively proliferating population of the SVZ, EGFresponsive NSCs were necessary and directly involved in replenishing the constitutively proliferating cells. Thus, we next asked whether aging animals would show a reduction in the capacity to replenish the constitutively proliferating population in the SVZ. We used AraC infusion into the lateral ventricle, which has been shown to result in a complete depletion of constitutively proliferating cells in the SVZ (Doetsch et al., 1999), and we then examined the reappearance of BrdU-IR cells over time (Fig. 6B). In the case of 2 -month-old animals, $40 \%$ of the constitutively proliferating population was restored after $4 \mathrm{~d}$, and repopulation was complete $8 \mathrm{~d}$ after the termination of AraC infusion. This is very similar to our previous studies using intranuclear radiation to kill the constitutively proliferating cells (Morshead et al., 1994). In the 24-monthold animals, complete repopulation was also observed; however, the time course for repopulation was markedly different. At both 4 and $8 \mathrm{~d}$ after AraC infusion, the percentage of recovery was significantly lower ( $p<0.05 ; n=3)$ than that for 2-month-old animals, and complete recovery was not seen until $14 \mathrm{~d}$. The latter is likely attributable to, at least in part, the longer cell cycle times in the aged constitutively proliferating population (Tropepe et al., 1997). In contrast, lengthening of the cell cycle is unlikely to underlie the reduced expansion in response to EGF (Fig. 6A), given that proliferation caused by both EGF and vehicle control infusions is measured in the same way in 24-month-old animals. In other words, both measures would have the same change in cell cycle time. Together, these findings animals per group.
Table 3. Reduction in forebrain NSC numbers in the adult mouse is independent of genetic background

\begin{tabular}{llll}
\hline \multirow{2}{*}{ Age } & \multicolumn{3}{l}{ Mouse strain } \\
\cline { 2 - 4 } \cline { 2 - 4 } BALB/c & CBA & DBA \\
\hline Number of neurospheres & & \\
2 Months & $834 \pm 21$ & $1158 \pm 147$ & $749 \pm 4$ \\
24 Months & $218 \pm 16^{* *}$ & $363 \pm 46^{* *}$ & $231 \pm 10^{* *}$ \\
\hline
\end{tabular}

The total number of neurospheres from the entire adult SVZ was determined as described in Materials and Methods. Data presented represent the mean \pm SEM ( $n=4$ animals in each group). ${ }^{* *} p<0.01$ versus 2 months.

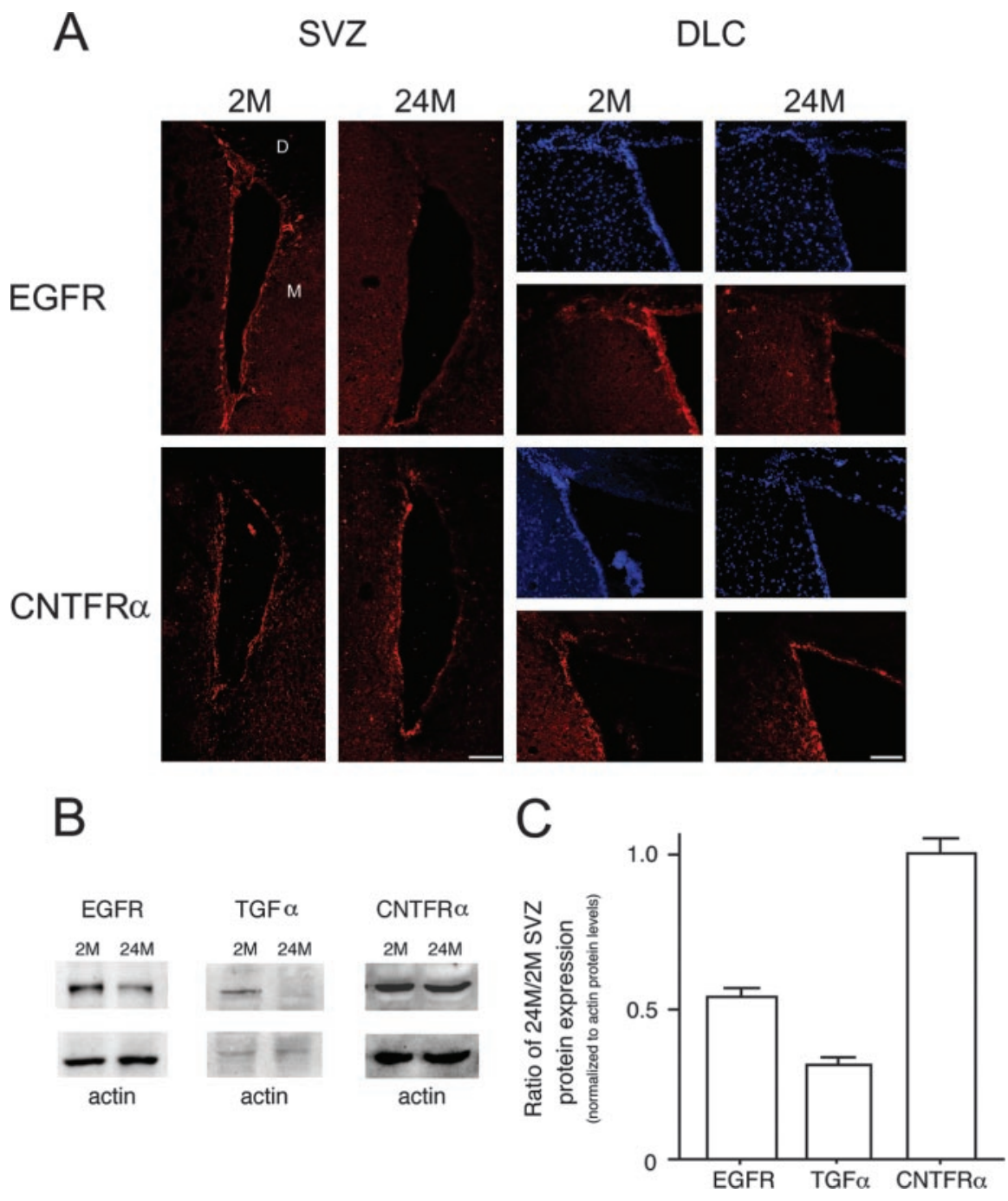

Figure 5. Aging results in decreased levels of expression of the EGFR and the EGFR ligand, TGF $\alpha$, within the adult SVZ. A, Immunohistochemical analysis of EGFR and CNTFR $\alpha$ expression in the SVZ of 2-month-old (2M) and 24-month-old (24M) mice. There are fewer cells expressing EGFR (red) in the SVZs of older mice (D, dorsal; M, medial). This becomes more apparent in a close-up of the dorsolateral corner (DLC) of the SVZ, where corresponding nuclear Hoechst staining (blue) illustrates the reduction in SVZ thickness. CNTFR $\alpha$ expression levels (red) were not different in the SVZs of 2-month-old and 24-month-old animals. Scale bars: SVZ panels (left), $100 \mu \mathrm{m}$; DLC panels (right), $50 \mu \mathrm{m}$. B, Western blot analysis of EGFR, TGF $\alpha$, CNTFR $\alpha$, and actin using protein isolated from the SVZs of 2- and 24-month-old mice. C, NIH imaging analysis (and normalization to the corresponding expression of actin) revealed that, in 24-month-old mice, EGFR expression levels were $\sim 50 \%$ lower than those in the younger mice $(p<0.05)$, TGF $\alpha$ levels were $\sim 70 \%$ lower $(p<0.05)$, and CNTFR $\alpha$ levels were unchanged. In all experiments, $n=3$

further support the contention that expansion of the constitutively proliferating population of the SVZ is significantly compromised in the aged forebrain, likely as a result of reduced EGFR signaling, whereas the intrinsic regenerative capacity of the SVZ is unchanged. 

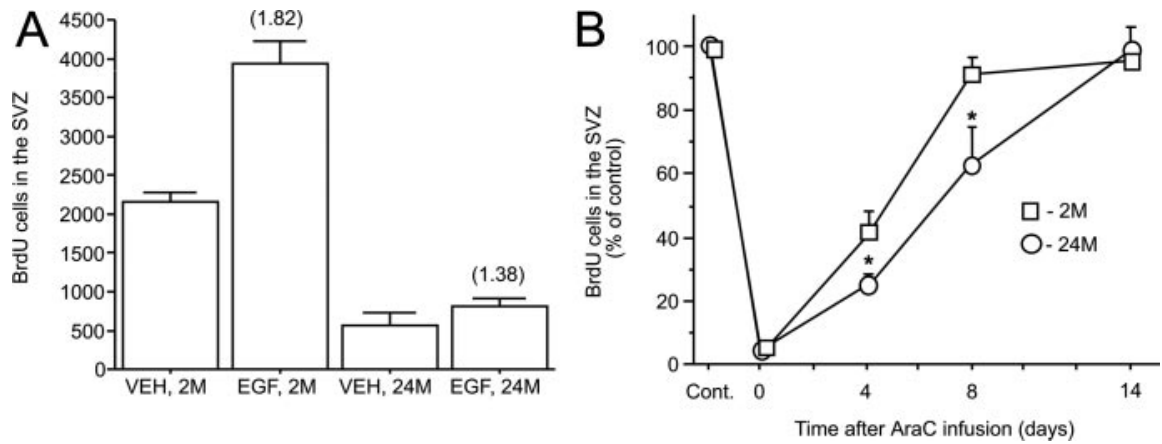

Figure 6. Aged neural stem cells and their progeny display a decreased capacity to respond to EGF infusion and a complete but slower time course for repopulating the SVZ. A, After a $3 \mathrm{~d}$ infusion of EGF, the number of BrdU-expressing cells in the SVZ of 2-month-old (2M) mice increased by $82 \%$ [compared with corresponding vehicle (VEH) controls; $p<0.05$ ], whereas BrdU cells in the SVZ of 24-month-old (24M) mice were increased by $38 \%(p<0.05)$. B, After a $3 \mathrm{~d}$ AraC kill, which destroyed the entire BrdU population, 2 -month-old mice repopulated after $8 \mathrm{~d}$, whereas 24 -month-old mice required $14 \mathrm{~d}$ for complete repopulation. ${ }^{*} p<$ 0.0.5 compared with 2-month-old mice at the same time point. Cont., Control.

A
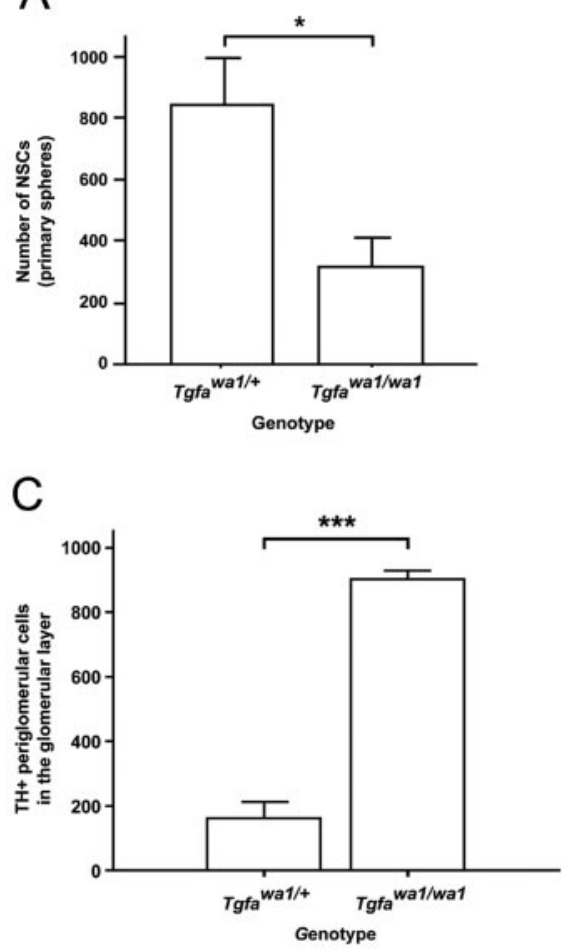

B
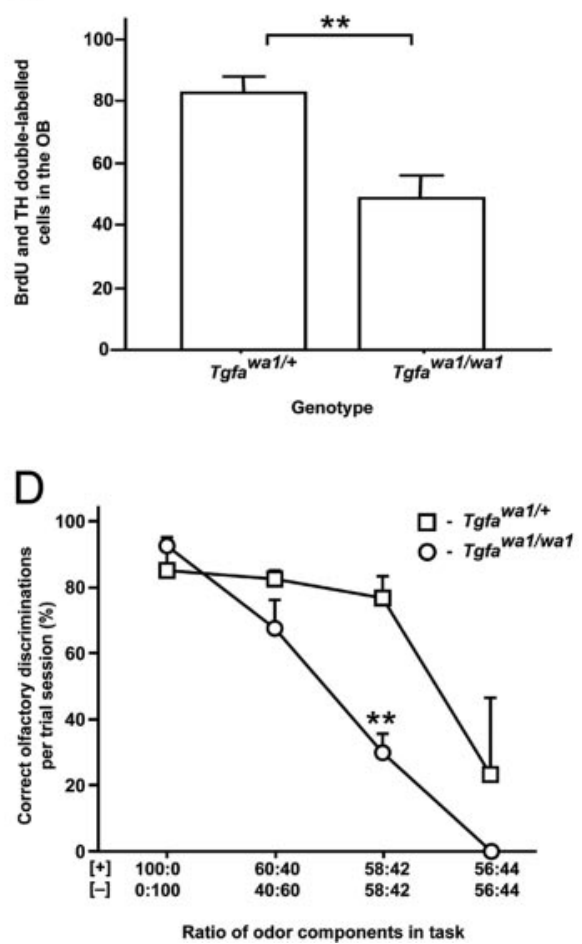

Figure 7. Waved-1 $\left(\operatorname{Tgfa}^{\text {wa1/wa1 }}\right)$ mice exhibit NSC, OB, and behavioral characteristics similar to the 24-month-old mice. $A$, There were fewer NSC-derived neurospheres produced from the $\operatorname{Tgfa}^{\text {wa1/wa1 }}$ mouse forebrains $(n=4)$ than from those of the heterozygous littermates $\left(\operatorname{Tgfa}^{\text {wa1/+}}\right)(n=4)$. B, The $\operatorname{Tgfa}^{\text {wa1/wa1 }}$ mice have more TH-positive periglomerular cells than their Tgfa $^{\text {wa1/+ }}$ counterparts. C, Tgfa ${ }^{\text {wa1/wa1 }}$ mice have fewer BrdU and TH double-labeled neurons in the OB 4 weeks after BrdU administration than the $T g f a^{\text {wa1/+ }}$ mice. $D$, The $\operatorname{Tgfa}^{\text {wa } 1 / \text { wa } 1}$ mice demonstrated poorer performance at fine olfactory discrimination than the Tgfa ${ }^{\text {wa1/+ }}$ mice. ${ }^{*} p<0.05 ;{ }^{* *} p<0.01$; ${ }^{* * *} p<0.001$; Student's $t$ test.

\section{Decreased EGFR signaling is sufficient to impair fine olfactory discrimination}

Our data show that aging results in an impairment in fine olfactory discrimination, possibly because of a decrease in neurogenesis and EGFR signaling in the forebrain. Thus, in a final series of experiments, we asked whether a reduction in EGFR signaling alone could mimic the reduction in NSC numbers, SVZ proliferation, and olfactory discrimination seen in aged mice. For these experiments, we used waved-1 ( $\left.T g f a^{\text {wal } / \text { wal }}\right)$ mice, which have spontaneous mutations that impart them with decreased levels of postnatal TGF $\alpha$ expression (Berkowitz et al., 1996; Burrows et al., 2000). These mice, like the aged mice, also have significantly reduced SVZ proliferation (Weickert and Blum, 1995). We asked whether the $T g f a^{\text {wal/wal }}$ have a reduced number of NSCs. We dissected out the SVZs of 2-month-old $T g f a^{\text {wal/wal }}$ mice and their phenotypically wild-type heterozygote $\left(T g f a^{\text {wall+ }}\right)$ littermates for neurosphere cultures. Tgfa $a^{\text {wal/wal }}$ mice contained fewer forebrain NSCs $(329 \pm 121$ neurospheres per brain; $p<0.05, n=4$ ) (Fig. 7A) than their Tgfa ${ }^{\text {wal/+ }}$ counterparts $(811 \pm 187$ neurospheres per brain). These differences are very similar to those seen between 2- and 24-month-old wild-type mice. The findings further demonstrate that EGFR signaling regulates the numbers of forebrain NSCs and likely underlies the reductions in numbers of NSC progeny seen in the aged SVZ. Consequently, we hypothesized that the $T g f a^{\text {wal/wal }}$ mice might phenocopy the aged mice in neurogenesis and number of olfactory interneurons in the OB. Tgfa $a^{w a 1 /+}$ and Tgfawal/wal mice were given injections of BrdU and perfused 4 weeks later. The $T g f a^{\text {wal } / w a l}$ mice had 59\% fewer BrdU/TH double-labeled cells in the OB than the $T g f a^{\text {wal/+ }}$ mice (Fig. $7 B)(p<0.05)$. As for the aging mice, we confirmed that the reduction in the genesis of TH interneurons is representative of a general OB interneuron phenomenon. First, we found that there were $57 \%$ $(p<0.01 ; n=3)$ fewer BrdU/calretinin double-labeled neurons in the glomerular layer of $T g f a^{w a 1 / w a l}$ mice. Second, there were $61 \%(p<0.01 ; n=3)$ and $44 \%(p<$ $0.01 ; n=3)$ fewer BrdU/GABA doublelabeled neurons in the granule and glomerular layers, respectively, in the Tgfa $a^{\text {wal/wal }}$ mice compared with their Tgfa ${ }^{\text {wall+ }}$ counterparts. Conversely, we found that the Tgfa ${ }^{\text {wal/wal }}$ mice had 5.5 times more $\mathrm{TH}$ positive neurons in the glomerular layer than their Tgfa $a^{\text {wal/+ }}$ counterparts (Fig. 7C) $(p<0.001 ; n=3)$. The phenotypes for both ongoing neurogenesis and total interneuron number in Tgfal wal mice, therefore, were again very similar to those of the 24-month-old mice. Finally, we asked whether fine olfactory discrimination was similarly compromised in the Tgfal $a^{\text {wal wal }}$ mice. On the olfactory discrimination generalization gradient, the Tgfa $a^{\text {wal/t }}$ and $T g f a^{\text {wal/wal }}$ mice performed identically at 100:0 and 60:40 concentration ratios (Fig. 7D). However, at 58:42, although the Tgfa $a^{\text {wal/+ }}$ averaged $77 \%$ success rates, the $T g f a^{\text {wal } / w a l}$ mice, averaging $30 \%$, performed significantly more poorly $(p<0.01 ; n=4)$. From these results, we concluded, along with the previously presented data, 
that the EGFR signaling-mediated reduction in neurogenesis led to impaired olfactory discrimination in aged and Tgfa $a^{\text {wal/wal }}$ mice, despite the overall increase in number of olfactory interneurons present in the $\mathrm{OB}$ in both animal models.

\section{Discussion}

\section{Localization of olfactory discrimination to the olfactory bulb} It is necessary to resolve essential differences in function between the $\mathrm{OE}$ and $\mathrm{OB}$ to specify that one structure, rather than the other, is responsible for a particular behavior. Under natural conditions, animals can be expected to face odors for which concentrations and purity vary widely from those experienced at initial presentation. Accurate detection of odors, therefore, requires sufficient olfactory sensitivity and discrimination capabilities on the part of the animal. A critical point of note with olfactory discrimination is that it depends to a significant extent on sensitivity, as discrimination becomes impossible if the sample is undetectable. This particular application of sensitivity to discrimination has been ascribed to the $\mathrm{OE}$ in previous studies (Youngentob et al., 1997; Duchamp-Viret et al., 2000; Kawai and Miyachi, 2001; Lansky and Getz, 2001; Kelliher et al., 2003). In the present study, by starting with $1 \mu$ l of odorant per sample and increasing this value by $750 \%$ during testing, we provided enough of the odorants in each sample, either alone or in mixture, to ensure that all animals could detect them without difficulty. This leaves the central olfactory pathway as a possible mediator of fine olfactory discrimination. Although other aspects of this pathway may indeed be involved, the results from the olfactory discrimination generalization gradient run with aged mice, $\mathrm{Lifr}^{+/-}$and Tgfa ${ }^{\text {wal/wal }}$ models collectively point to the OB, and specifically to the effects brought about by a reduction in levels of neurogenesis.

The evidence suggesting a role for neurogenesis in olfactory discrimination arose from such studies as that by Gheusi et al. (2000) comparing the olfactory behavior of NCAM mutant mice to that of their wild-type counterparts. They reported that the NCAM mutant mice were impaired at discrete olfactory discriminations. Surprisingly, in the present study, using three separate phenotypically analogous animal models, we saw no evidence of differences between groups in this form of discrimination. It is possible that the reason for this discrepancy lies in the methodological differences in the approach used, because our tasks focused more on the responses of the mice to various odors than to their locomotor behavior over time with respect to the odors, as was the case in the study by Gheusi et al. (2000). Furthermore, olfactory learning plays a significant role in assessment of olfactory discrimination, because the animals must learn and remember the odors, particularly when they are similar, before they can effect discrimination in either task. The olfactory discrimination generalization gradient required that the animals meet certain base criteria for learning before data were recorded from trials. The task used by Gheusi et al. (2000) did not have this requirement, raising the possibility that NCAM mutant mice may have had an uncharacterized learning deficit that affected their performance on the discrimination task. In fact, the role of NCAM in learning and memory has been documented extensively (Arami et al., 1996; Mileusnic et al., 1999; Cremer et al., 2000; Ronn et al., 2000; Stork et al., 2000).

\section{NSC numbers and neurogenesis show a parallel reduction during aging}

In the present study, we found that NSC numbers in the murine forebrain SVZ do in fact decrease profoundly with age, possibly impairing neurogenesis and, eventually, olfactory discrimination. In a previous study, although Tropepe et al. (1997) reported an age-dependent reduction in proliferation in the SW/COBS mouse forebrain SVZ, they found no reduction in the number of NSCs. These differences in reported findings may be attributable to variations in the ability to obtain NSCs from the adult SVZ. The likelihood that genetic background is important is largely ruled out by our analysis of four different mouse strains, each of which showed a virtually identical reduction in NSC number. In a related study, the same group (Morshead et al., 1998) used in vivo clonal lineage analysis to determine that there are 1200-1300 NSCs in the adult murine rostral forebrain SVZ. Our forebrain NSC cultures yield $\sim 900$ neurospheres per brain for a clonal efficiency of $\sim 75 \%$, whereas Tropepe et al. (1997) generated $\sim 130$ neurospheres per brain for a clonal efficiency of $\sim 10 \%$. Furthermore, a very recent study has found (using both a new marker for forebrain NSCs and the neurosphere assay) that there is a reduction with age (Maslov et al., 2004). Together, this reinforces the conclusion that aged mice demonstrate reductions in NSC number.

The concept that NSCs directly or indirectly control the extent of olfactory neurogenesis suggests that neurogenesis will increase when NSC numbers increase and vice versa. Our results demonstrate that adult forebrain mouse NSC numbers, SVZ proliferation, and the numbers of neuronal progenitors in the dorsolateral corner of the SVZ and RMS are proportionally reduced (up to $75 \%$ in 24 -month-old mice) with age. These findings further confirm our position, again based on our previous studies (Morshead et al., 1994; Shimazaki et al., 2001) that NSC numbers determine, to the largest degree, the absolute extent of adult forebrain neurogenesis. Interestingly, the number of $\mathrm{TH}$ interneurons in the OB increases significantly (44\%) over the same time period. Although Mirich et al. (2002) reported a general increase in the size of the glomerular layer, they found that $\mathrm{TH}$ immunoreactivity (measured by semiquantitative densitometry) was unchanged between 6- and 24-month-old C57BL/6J mice, the same principal strain used in this study. The difference may be attributable to the differences in assessment or the possibility that changes in total TH number occur between 2 and 6 months of age. Nevertheless, the fact that they also observed a reduction in neurogenesis with an increase in total cell number during aging raises the possibility, which has been addressed previously (Jankovski et al., 1998; Kirschenbaum et al., 1999; Rochefort et al., 2002), that the OB exerts a level of feedback control on neurogenesis at the level of the NSC, which may only manifest over extended periods of time. The reduction in EGF signaling, without an apparent reduction in the intrinsic regenerative capacity of the SVZ, suggests that the feedback act at the level of the specific signals that regulate the size of the olfactory precursor pool.

\section{The effect of reduced EGFR signaling with age on NSC numbers}

Previous work from our laboratory implicates EGF and CNTF receptor signaling in regulating NSC population and progenitor proliferation in vitro and in vivo (Reynolds and Weiss, 1992; Morshead et al., 1994; Shimazaki et al., 2001). We observed no reduction in the expression levels of CNTFR $\alpha$ in the SVZ with age, suggesting that this signaling pathway was unlikely to be responsible for the observed age-related changes. In contrast, the aged forebrain SVZ did exhibit significant reductions in the expression of both EGFR and TGF $\alpha$. Furthermore, the TGF $\alpha$ hypomorphic 
mice, $T g f a^{\text {wal } / w a l}$, demonstrated many phenotypic similarities to the aged mice. $T g f a^{\text {wal/wal }}$ and aged mice exhibited similar reductions in the numbers of forebrain NSCs and in SVZ proliferation compared with $T g f a^{\text {wal/+ }}$ or young adult mice, respectively. Remarkably, both Tgfa $a^{\text {wal/wal }}$ and aged mice also displayed increased numbers of olfactory interneurons relative to $\mathrm{Tg} \mathrm{fa}^{\text {wal/+ }}$ or young mice, respectively. The increase in the number of interneurons with age is likely attributable to the accumulated effect of neurogenesis over time. However, this phenomenon is more difficult to explain in the age-matched Tgfa $a^{\text {wal/wal }}$ and $T g f a^{\text {wal/+ }}$ mice. There is evidence that under certain conditions, EGFR signaling can increase cellular apoptosis (Gulli et al., 1996; Smida Rezgui et al., 2000; Yoshimoto and Imoto, 2002; Purdom and Chen, 2003; Kamer et al., 2004; Tikhomirov and Carpenter, 2004). It is possible that the reduction in EGFR signaling in $T g f a^{\text {wal/wal }}$ mice acts to promote survival of the olfactory interneurons at the level of the bulb. Nevertheless, the evidence presented here supports our position that EGFR signaling is critical in maintaining NSC numbers and, consequently, in the production of new neurons in the OB.

\section{The necessity of olfactory neurogenesis in control of fine olfactory discrimination}

It seems reasonable to propose that a role for new olfactory neurons in fine olfactory discrimination may have arisen to allow for dynamic control over the sense of smell. For animals that rely principally on their sense of smell to perform their various life functions of feeding, mating, and predator evasion, it may be critical to identify and resolve novel odors through enhanced odor discrimination. In turn, it follows that these needs, and the physiological mechanisms that subserve them, likely diminish over time. Nevertheless, certain situations may call for plasticity in the neural circuitry mediating these behaviors; one such situation is pregnancy, which triggers a sudden increase in neurogenesis (Shingo et al., 2003). The influx of new neurons to the OB during parturition may improve olfactory discrimination, allows for the establishment of new engrams, and thus enables the mother to identify her young. Experiments with sheep show that parturition induces the release of oxytocin (Levy et al., 1995) (which in itself was sufficient to increase levels of GABA), which, based on the principles of lateral inhibition (Urban, 2002; Aungst et al., 2003; Egger et al., 2003; Schoppa and Urban, 2003), may also increase discrimination capabilities. Also, recent reports that novel odors enhance the survival of new olfactory interneurons (Petreanu and Alvarez-Buylla, 2002; Rochefort et al., 2002) and that these neurons become physiologically active soon after arrival in the OB (Belluzzi et al., 2003; Carleton et al., 2003) constitute additional evidence that these new neurons may play functionally important roles. Given that newly generated granule cells of the adult hippocampus display specific ion channel properties that endow them with enhanced synaptic plasticity (SchmidtHieber et al., 2004), it may be that newly generated adult olfactory interneurons have similar advantages for the performance of fine olfactory discrimination.

In conclusion, it would appear that ongoing adult neurogenesis forms part of a system that is adaptable to the needs of the animal, responsive to the conditions of the environment, and receptive to highly variant stimuli. These capabilities may diminish with age, and it seems tempting to speculate that this may underlie reported deficits in olfactory discrimination observed with human aging (Stevens and Cain, 1987; Hulshoff Pol et al.,
2000; Kaneda et al., 2000). However, although recent evidence indicates that NSCs are present in the SVZ of the adult human forebrain, adult humans apparently lack a RMS (Sanai et al., 2004). This unexpected finding is inconsistent with evidence from studies with primates considered to be analogous to humans until now (Kornack and Rakic, 2001). Because both NSCs and new neurons are apparently present in the human $\mathrm{OB}(\mathrm{Pa}-$ gano et al., 2000; Liu and Martin, 2003), it seems possible that different mechanisms apply to produce the same effect in both humans and mice. In vitro assays and postmortem analyses comparing neurogenesis in the SVZ and OB of young and aged mice and humans may shed additional light on these remarkable functions.

\section{References}

Altman J (1969) Autoradiographic and histological studies of postnatal neurogenesis. IV. Cell proliferation and migration in the anterior forebrain, with special reference to persisting neurogenesis in the olfactory bulb. J Comp Neurol 137:433-457.

Altman J, Das GD (1966) Autoradiographic and histological studies of postnatal neurogenesis. I. A longitudinal investigation of the kinetics, migration and transformation of cells incorporating tritiated thymidine in neonate rats, with special reference to postnatal neurogenesis in some brain regions. J Comp Neurol 126:337-389.

Arami S, Jucker M, Schachner M, Welzl H (1996) The effect of continuous intraventricular infusion of L1 and NCAM antibodies on spatial learning in rats. Behav Brain Res 81:81-87.

Aungst JL, Heyward PM, Puche AC, Karnup SV, Hayar A, Szabo G, Shipley MT (2003) Centre-surround inhibition among olfactory bulb glomeruli. Nature 426:623-629.

Belluzzi O, Benedusi M, Ackman J, LoTurco JJ (2003) Electrophysiological differentiation of new neurons in the olfactory bulb. J Neurosci 23:10411-10418.

Berkowitz EA, Seroogy KB, Schroeder JA, Russell WE, Evans EP, Riedel RF, Phillips HK, Harrison CA, Lee DC, Luetteke NC (1996) Characterization of the mouse transforming growth factor alpha gene: its expression during eyelid development and in waved 1 tissues. Cell Growth Differ 7:1271-1282.

Burrows RC, Levitt P, Shors TJ (2000) Postnatal decrease in transforming growth factor alpha is associated with enlarged ventricles, deficient amygdaloid vasculature and performance deficits. Neuroscience 96:825-836.

Carlen M, Cassidy RM, Brismar H, Smith GA, Enquist LW, Frisen J (2002) Functional integration of adult-born neurons. Curr Biol 12:606-608.

Carleton A, Petreanu LT, Lansford R, Alvarez-Buylla A, Lledo PM (2003) Becoming a new neuron in the adult olfactory bulb. Nat Neurosci 6:507-518.

Chojnacki A, Shimazaki T, Gregg C, Weinmaster G, Weiss S (2003) Glycoprotein 130 signaling regulates Notch1 expression and activation in the self-renewal of mammalian forebrain neural stem cells. J Neurosci 23:1730-1741.

Conley DB, Robinson AM, Shinners MJ, Kern RC (2003) Age-related olfactory dysfunction: cellular and molecular characterization in the rat. Am J Rhinol 17:169-175.

Cremer H, Chazal G, Lledo PM, Rougon G, Montaron MF, Mayo W, Le Moal M, Abrous DN (2000) PSA-NCAM: an important regulator of hippocampal plasticity. Int J Dev Neurosci 18:213-220.

Doetsch F, Garcia-Verdugo JM, Alvarez-Buylla A (1997) Cellular composition and three-dimensional organization of the subventricular germinal zone in the adult mammalian brain. J Neurosci 17:5046-5061.

Doetsch F, Garcia-Verdugo JM, Alvarez-Buylla A (1999) Regeneration of a germinal layer in the adult mammalian brain. Proc Natl Acad Sci USA 96:11619-11624.

Duchamp-Viret P, Duchamp A, Chaput MA (2000) Peripheral odor coding in the rat and frog: quality and intensity specification. J Neurosci 20:2383-2390.

Egger V, Svoboda K, Mainen ZF (2003) Mechanisms of lateral inhibition in the olfactory bulb: efficiency and modulation of spike-evoked calcium influx into granule cells. J Neurosci 23:7551-7558. 
Gheusi G, Cremer H, McLean H, Chazal G, Vincent JD, Lledo PM (2000) Importance of newly generated neurons in the adult olfactory bulb for odor discrimination. Proc Natl Acad Sci USA 97:1823-1828.

Giardino L, Bettelli C, Calza L (2000) In vivo regulation of precursor cells in the subventricular zone of adult rat brain by thyroid hormone and retinoids. Neurosci Lett 295:17-20.

Gulli LF, Palmer KC, Chen YQ, Reddy KB (1996) Epidermal growth factorinduced apoptosis in A431 cells can be reversed by reducing the tyrosine kinase activity. Cell Growth Differ 7:173-178.

Hulshoff Pol HE, Hijman R, Baare WF, van Eekelen S, van Ree JM (2000) Odor discrimination and task duration in young and older adults. Chem Senses 25:461-464.

Isaacson JS, Vitten H (2003) GABA(B) receptors inhibit dendrodendritic transmission in the rat olfactory bulb. J Neurosci 23:2032-2039.

Jankovski A, Garcia C, Soriano E, Sotelo C (1998) Proliferation, migration and differentiation of neuronal progenitor cells in the adult mouse subventricular zone surgically separated from its olfactory bulb. Eur J Neurosci 10:3853-3868.

Kamer AR, Sacks PG, Vladutiu A, Liebow C (2004) EGF mediates multiple signals: dependence on the conditions. Int J Mol Med 13:143-147.

Kaneda H, Maeshima K, Goto N, Kobayakawa T, Ayabe-Kanamura S, Saito S (2000) Decline in taste and odor discrimination abilities with age, and relationship between gustation and olfaction. Chem Senses 25:331-337.

Kaser MR, Lakshmanan J, Fisher DA (1992) Comparison between epidermal growth factor, transforming growth factor-alpha and EGF receptor levels in regions of adult rat brain. Brain Res Mol Brain Res 16:316-322.

Kasowski HJ, Kim H, Greer CA (1999) Compartmental organization of the olfactory bulb glomerulus. J Comp Neurol 407:261-274.

Kawai F, Miyachi E (2001) Enhancement by T-type $\mathrm{Ca}^{2+}$ currents of odor sensitivity in olfactory receptor cells. J Neurosci 21:RC144.

Kelliher KR, Ziesmann J, Munger SD, Reed RR, Zufall F (2003) Importance of the CNGA4 channel gene for odor discrimination and adaptation in behaving mice. Proc Natl Acad Sci USA 100:4299-4304.

Kirschenbaum B, Doetsch F, Lois C, Alvarez-Buylla A (1999) Adult subventricular zone neuronal precursors continue to proliferate and migrate in the absence of the olfactory bulb. J Neurosci 19:2171-2180.

Kornack DR, Rakic P (2001) The generation, migration, and differentiation of olfactory neurons in the adult primate brain. Proc Natl Acad Sci USA 98:4752-4757.

Kosaka K, Toida K, Aika Y, Kosaka T (1998) How simple is the organization of the olfactory glomerulus?: the heterogeneity of so-called periglomerular cells. Neurosci Res 30:101-110.

Lansky P, Getz WM (2001) Receptor heterogeneity and its effect on sensitivity and coding range in olfactory sensory neurons. Bull Math Biol 63:885-908.

Laurent G (1999) A systems perspective on early olfactory coding. Science 286:723-728.

Levy F, Kendrick KM, Goode JA, Guevara-Guzman R, Keverne EB (1995) Oxytocin and vasopressin release in the olfactory bulb of parturient ewes: changes with maternal experience and effects on acetylcholine, gammaaminobutyric acid, glutamate and noradrenaline release. Brain Res 669:197-206.

Liu Z, Martin LJ (2003) Olfactory bulb core is a rich source of neural progenitor and stem cells in adult rodent and human. J Comp Neurol 459:368-391.

Lois C, Alvarez-Buylla A (1994) Long-distance neuronal migration in the adult mammalian brain. Science 264:1145-1148.

Loo AT, Youngentob SL, Kent PF, Schwob JE (1996) The aging olfactory epithelium: neurogenesis, response to damage, and odorant-induced activity. Int J Dev Neurosci 14:881-900.

Luskin MB (1993) Restricted proliferation and migration of postnatally generated neurons derived from the forebrain subventricular zone. Neuron 11:173-189.

Machold R, Hayashi S, Rutlin M, Muzumdar MD, Nery S, Corbin JG, GritliLinde A, Dellovade T, Porter JA, Rubin LL, Dudek H, McMahon AP, Fishell G (2003) Sonic hedgehog is required for progenitor cell maintenance in telencephalic stem cell niches. Neuron 39:937-950.

Maslov AY, Barone TA, Plunkett RJ, Pruitt SC (2004) Neural stem cell detection, characterization, and age-related changes in the subventricular zone of mice. J Neurosci 24:1726-1733.
Mileusnic R, Lancashire C, Rose SP (1999) Sequence-specific impairment of memory formation by NCAM antisense oligonucleotides. Learn Mem 6:120-127.

Mirich JM, Williams NC, Berlau DJ, Brunjes PC (2002) Comparative study of aging in the mouse olfactory bulb. J Comp Neurol 454:361-372.

Morshead CM, Reynolds BA, Craig CG, McBurney MW, Staines WA, Morassutti D, Weiss S, van der Kooy D (1994) Neural stem cells in the adult mammalian forebrain: a relatively quiescent subpopulation of subependymal cells. Neuron 13:1071-1082.

Morshead CM, Craig CG, van der Kooy D (1998) In vivo clonal analyses reveal the properties of endogenous neural stem cell proliferation in the adult mammalian forebrain. Development 125:2251-2261.

Ohta Y, Ichimura K (2000) Proliferation markers, proliferating cell nuclear antigen, Ki67, 5-bromo-2'-deoxyuridine, and cyclin D1 in mouse olfactory epithelium. Ann Otol Rhinol Laryngol 109:1046-1048.

Pagano SF, Impagnatiello F, Girelli M, Cova L, Grioni E, Onofri M, Cavallaro M, Etteri S, Vitello F, Giombini S, Solero CL, Parati EA (2000) Isolation and characterization of neural stem cells from the adult human olfactory bulb. Stem Cells 18:295-300.

Petreanu L, Alvarez-Buylla A (2002) Maturation and death of adult-born olfactory bulb granule neurons: role of olfaction. J Neurosci 22:6106-6113.

Purdom S, Chen QM (2003) Linking oxidative stress and genetics of aging with p66Shc signaling and forkhead transcription factors. Biogerontology 4:181-191.

Reynolds BA, Weiss S (1992) Generation of neurons and astrocytes from isolated cells of the adult mammalian central nervous system. Science 255:1707-1710.

Rochefort C, Gheusi G, Vincent JD, Lledo PM (2002) Enriched odor exposure increases the number of newborn neurons in the adult olfactory bulb and improves odor memory. J Neurosci 22:2679-2689.

Ronn LC, Berezin V, Bock E (2000) The neural cell adhesion molecule in synaptic plasticity and ageing. Int J Dev Neurosci 18:193-199.

Rosli Y, Breckenridge LJ, Smith RA (1999) An ultrastructural study of agerelated changes in mouse olfactory epithelium. J Electron Microsc (Tokyo) 48:77-84.

Sanai N, Tramontin AD, Quinones-Hinojosa A, Barbaro NM, Gupta N, Kunwar S, Lawton MT, McDermott MW, Parsa AT, Manuel-Garcia Verdugo J, Berger MS, Alvarez-Buylla A (2004) Unique astrocyte ribbon in adult human brain contains neural stem cells but lacks chain migration. Nature 427:740-744.

Schmidt-Hieber C, Jones P, Bischofberger J (2004) Enhanced synaptic plasticity in newly generated granule cells of the adult hippocampus. Nature 429:184-187.

Schoppa NE, Urban NN (2003) Dendritic processing within olfactory bulb circuits. Trends Neurosci 26:501-506.

Schoppa NE, Kinzie JM, Sahara Y, Segerson TP, Westbrook GL (1998) Dendrodendritic inhibition in the olfactory bulb is driven by NMDA receptors. J Neurosci 18:6790-6802.

Scott JW, Wellis DP, Riggott MJ, Buonviso N (1993) Functional organization of the main olfactory bulb. Microsc Res Tech 24:142-156.

Shimazaki T, Shingo T, Weiss S (2001) The ciliary neurotrophic factor/leukemia inhibitory factor/gp130 receptor complex operates in the maintenance of mammalian forebrain neural stem cells. J Neurosci 21:7642-7653.

Shingo T, Sorokan ST, Shimazaki T, Weiss S (2001) Erythropoietin regulates the in vitro and in vivo production of neuronal progenitors by mammalian forebrain neural stem cells. J Neurosci 21:9733-9743.

Shingo T, Gregg C, Enwere E, Fujikawa H, Hassam R, Geary C, Cross JC, Weiss S (2003) Pregnancy-stimulated neurogenesis in the adult female forebrain mediated by prolactin. Science 299:117-120.

Shipley MT, Ennis M (1996) Functional organization of olfactory system. J Neurobiol 30:123-176.

Smida Rezgui S, Honore S, Rognoni JB, Martin PM, Penel C (2000) Upregulation of alpha 2 beta 1 integrin cell-surface expression protects A431 cells from epidermal growth factor-induced apoptosis. Int J Cancer 87:360-367.

Stevens JC, Cain WS (1987) Old-age deficits in the sense of smell as gauged by thresholds, magnitude matching, and odor identification. Psychol Aging 2:36-42. 
Stork O, Welzl H, Wolfer D, Schuster T, Mantei N, Stork S, Hoyer D, Lipp H, Obata K, Schachner M (2000) Recovery of emotional behaviour in neural cell adhesion molecule (NCAM) null mutant mice through transgenic expression of NCAM180. Eur J Neurosci 12:3291-3306.

Tikhomirov O, Carpenter G (2004) Ligand-induced, p38-dependent apoptosis in cells expressing high levels of EGF receptor and ErbB-2. J Biol Chem 279:12988-12996.

Tropepe V, Craig CG, Morshead CM, van der Kooy D (1997) Transforming growth factor-alpha null and senescent mice show decreased neural progenitor cell proliferation in the forebrain subependyma. J Neurosci 17:7850-7859.

Urban NN (2002) Lateral inhibition in the olfactory bulb and in olfaction. Physiol Behav 77:607-612.

Weickert CS, Blum M (1995) Striatal TGF-alpha: postnatal developmental expression and evidence for a role in the proliferation of subependymal cells. Brain Res Dev Brain Res 86:203-216.

Weiler E, Farbman AI (1997) Proliferation in the rat olfactory epithelium: age-dependent changes. J Neurosci 17:3610-3622.

Weiss S, Dunne C, Hewson J, Wohl C, Wheatley M, Peterson AC, Reynolds BA (1996) Multipotent CNS stem cells are present in the adult mammalian spinal cord and ventricular neuroaxis. J Neurosci 16:7599-7609.

Yoshimoto Y, Imoto M (2002) Induction of EGF-dependent apoptosis by vacuolar-type $\mathrm{H}(+)$-ATPase inhibitors in A431 cells overexpressing the EGF receptor. Exp Cell Res 279:118-127.

Youngentob SL, Schwob JE, Sheehe PR, Youngentob LM (1997) Odorant threshold following methyl bromide-induced lesions of the olfactory epithelium. Physiol Behav 62:1241-1252. 